\title{
Mavens, Mavericks, and Managers: Educational Projecting and Politicking in Petrine and Post-Petrine Russia
}

\author{
Paul Keenan \\ London School of Economics and Political Science \\ p.keenan@lse.ac.uk
}

Igor Fedyukin, The Enterprisers: The Politics of School in Early Modern Russia, Oxford University Press: Oxford, 2019; 328p. ISBN: 9780190845001.

The book opens with a telling episode for anyone who has experience of the vagaries of academic administration and governance. This is the case of the monk Sil'vestr Medvedev, who penned the "first-ever project for a school charter in Russia," Привилегия на Академию (or "Academic Privilege"), in the early 1680s, which proposed both a new educational institution (the eponymous academy) and also a monopolistic control of education across Russia. However, Medvedev was then the victim of two developments that derailed his planned project decisively: the preference given to the academy proposal of the Leichoudes brothers; and his arrest after the fall of his patron the regent Sofiia Alekseevna in 1689, which led to his execution in 1691. Despite this ignominious end, Medvedev and his ambitious, wide-ranging "Privilege" provides an illustration of the processes and relationships that Fedyukin explores in this detailed and stimulating monograph. It examines the subject of education and schooling in Russia in the very significant transitional era between the mid-late seventeenth century and the 1760 s. Fedyukin has researched and written extensively about this topic for almost two decades, with a dozen or so articles and chapters devoted to specific individuals, institutions and themes, as well as several edited collections of related materials. As such, he is able to draw on a very wide-ranging and detailed knowledge of both the subject matter and its historiography. This monograph represents something of a capstone achievement for this endeavor and makes a significant contribution to the ongoing revisionist approach to the historiography on policy-making and institutional change in early modern Russia.

The subject of education has long been associated with the Petrine Revolution, wherein the creation of "modern" schools in this period was part of the great reforming tsar's efforts to drag/push Russia forwards. Unsurprisingly, both the broader interpretation of Peter's "grand plan" and the specific dynamics of particular elements within it, such as education, have been the subject of fruitful, sophisticated revisionist scholarship for several decades now. Fedyukin's work demonstrates an extensive and well-rounded grasp of this evolving historiography. His chosen focus and the archivallygrounded approach of the main chapters resonates clearly and constructively with the ongoing work in the field, while making clear his own interpretative position. Principally, Fedyukin is interested in the role of what he terms "administrative entrepreneurs" (or "enterprisers") in establishing and developing projects that resulted in the creation of "new" institutions, or institutional change for those already in 
existence. This approach is inspired by the work of Jan Glete, amongst others, who have examined the impact of innovation and entrepreneurship on early modern state institutions. Such "projectors", as contemporaries often termed them, were inextricably linked to the existing and shifting political realities of their situation, which could have a very significant impact on the nature and extent of their outcomes. As reflected in the scholarship on the period, both for Russia and for most other early modern states, the growing size and sophistication of the state apparatus needs to be considered alongside (and understood in light of) the persistence of formal and informal hierarchies and networks. Any proposal by such "enterprisers" had to negotiate these complexities very carefully in pursuit the necessary influence, resources, and support to realize and then build upon their aims.

Fedyukin takes this approach to the development of schools - and, by extension, educational institutions and policies more generally - in Russia, arguing that the process of innovation and change in this period was driven largely by the efforts of individual "enterprisers," rather than as a result of the direct intervention of the ruler or state bodies. Even in the reign of a famously "hands-on" ruler such as Peter, who could reasonably be described as a projector in his own right, their contribution was typically in the form of establishing an environment which encouraged (explicitly or implicitly) the "projecting" efforts of such individuals and setting out (however broadly) priorities for prospective projects. Given this emphasis on the agency and interests of individual "projectors," and their somewhat ambivalent reputation amongst contemporaries, there has been a tendency to view such activities in a cynical and opportunistic light. Instead Fedyukin highlights the importance of recognizing there was a "heterogeneity of agendas" at work (p. 15), wherein those involved in a given project commonly sought outcomes that served a number of purposes - personal gain and significant institutional change were not mutually exclusive outcomes. This point also reinforces the argument that "projecting" could be approached in a number of different ways. He identifies three broad categories of administrative entrepreneur by way of illustration, although also noting that individuals could fall into more than one category in a given situation. The first and most recognizable form of projector was "the expert." who asserted knowledge, expertise or experience in a given field as the basis for their proposal. The second was "the minister" (although, in my view, "the dignitary" would be a more apt summation), who was in an established position to provide patronage and promotion for a given project. Finally, there was "the functionary," who were typically from the lower ranks of officialdom and may arise from amongst practitioners (in the case of schools, this could be a teacher, for example). Each category had distinct but connected roles to play in a given project, from its inception to its realization and development. Fedyukin's purpose is to examine educational projects in Russia during the early-mid eighteenth century in order to shed new light on these relationships and their impact on the realization (or otherwise) of said projects.

The first chapter examines the state of education in Russia during the second half of the seventeenth century in order to establish the context for a critical exploration of the relationship between Peter I and education. The educational developments of the period arose from the efforts of individuals like the aforementioned Leichoudes brothers and later Archbishop Feofan Prokopovich to pursue, establish and develop the project, based on their own convictions and drawing on an environment conducive to the influx of Greek- and Ukrainian-influenced personnel and practices. In the main, 
however, this period reflected the established educational model - a master working with their pupils or apprentices - and this had been the case for Peter himself. However, it was also a common model across the rest of Europe, as reflected in the experience of the young Russian nobles sent abroad to study subjects such as navigation from the late 1690 onwards. Fedyukin notes that Peter's views on education and schooling - as reflected in his notebooks and correspondence, for example - were rarely, if ever, detailed or specific on methods and content. As a result, despite Peter's interest in particular subjects that could be delivered by formal educational institutions, he did not offer direct, sustained support for their development during his reign. Rather, as noted in the introduction, his reign (and those of his successors) fostered the gradual expansion of institutional and educational space that offered opportunities for projectors, in which Catholic and Protestant influences emerged to join the aforementioned Orthodox models of the preceding era.

The following three chapters explore the projecting that arose from the educational requirements associated with the development of one of Peter's well-known passions the Russian navy. Given the technical and "foreign" nature of the navy in this formative period of its history, it has often been linked with the establishment of "modern" schools and therefore Russia's emergence or transformation under Peter the Great. However, as Fedyukin explores in a series of detailed and illuminating case studies, the schools that arose in connection with the navy provide ample evidence to support the argument that they provided precisely the kind of opportunities that attracted the attention of competing administrative entrepreneurs. While the institutions-the School of Mathematics and Navigation, and the Naval Academy-

have been the subject of various studies, Fedyukin's concern is with their role in the projecting by those seeking to either establish (or sometimes rehabilitate) their position in Russia. Such enterprisers used the schools to establish a platform in order to secure resources and build networks of influence, particularly in terms of patronage. Strikingly, few of these enterprisers came from a naval background-those that did often lacked campaign experience-but compensated with influential connections and active engagement with supporting interests. Indeed, as discussed in Chapter 4, when experienced professional sailors were appointed by the Admiralty to run the Naval Academy in the 1730s, there was little enthusiasm or support for educational reform and intakes at both schools were in decline. The most detailed project from this period came from the efforts of Heinrich Ostermann, an experienced and influential figure certainly, but one who had no previous connection with the navy. Instead, his efforts resulted from a desire to implement a Pietist-inspired pedagogical program and to have an influential position at the head of the naval establishment from which to counterbalance the influence of rivals in court/state affairs.

Fedyukin's discussion in these chapters highlights some fascinating figures. For example, Aleksei A. Kurbatov, a serf in Boris P. Sheremetev's service who rose to a position of influence in the Moscow Armory, played a crucial role in the development of the School of Mathematics and Navigation because of the latitude made possible by his superior Fedor A. Golovin, his cultivation of support amongst Moscow книжники circles, and patronage of likeminded "functionaries" (particularly Andrei A. Beliaev and Leontii F. Magnitskii) who could then use their position to pursue projects of their own. Likewise, the establishment of the Naval Academy provides an opportunity to examine the remarkable case of Baron Joseph de Saint-Hilaire, an imposter and opportunist par 
excellence who inveigled himself into Russian court circles in 1715. Saint-Hilaire sought to consolidate this position through the submission of proposals for the nascent institution and other ambitious naval projects on the basis of "expertise" and his favorable connections. However, he fell afoul of Andrei A. Matveev, who was appointed to oversee the Academy after his return from diplomatic service. Matveev knew something of the Baron's murky past and was better placed to win the subsequent struggle between them. Yet while Saint-Hilaire was ultimately unsuccessful in this endeavor, his proposals were detailed, drawing on an established French model, and proved reasonably influential in subsequent developments.

The case of Saint-Hilaire serves to illustrate that such projects could not simply rely on appealing to the tsar's professed commitment to order and regularity, since the broad contours of these concepts left room for rival interpretations and realization of such goals. Fedyukin argues that these "modern" qualities were not intrinsic to any of these institutions precisely because of the manner in which they evolved under the influence of competing projectors and practical realities. In this regard, he highlights the resistance the mooted move to a parallel curriculum (per the French model), which was approved in the early 1720 s, but was overturned after concerted efforts by teachers at the naval schools to defend their established (traditional) sequential model on pedagogical and practical grounds, albeit also for political reasons. By the final years of Peter's reign, the Academy and the other educational institutions, including the remaining cypher schools, had come under the directorship of his cousin, Aleksandr L. Naryshkin (one of those who had studied navigation abroad), who played a straight bat to any requests for further instructions or regulations. His priorities, and indeed those of the Admiralty, lay elsewhere, which led into the situation in the 1730s, discussed above.

By contrast to the languishing of the naval schools, Chapter 5 focuses on the successes of the Noble Cadet Corps, sometimes heralded as Russia's first "truly modern school" (p. 134), from its establishment in 1731. Fedyukin situates it in the confluence between several important factors - the political ferment of the early 1730s, the energetic ambitions of Burkhard Christoph von Münnich, and the influence of Pietist ideas on educational reform. He outlines a convincing case that von Münnich was not involved in the initial stages of planning for the Cadet Corps, despite his evident interest in education and regulation. Rather, he was rewarded for his service under Peter I, when he oversaw the completion of the Ladoga canal project, and for his political alignment with the "German" court faction - Ostermann, Karl Gustav von Löwenwolde, and Anna's favorite, Ernst Johann von Bühren. His appointment as director-general of the Corps was part of a rapid and remarkable ascent in the course of the next few years, including the post of Generalfeldzeugmeister, president of the War College, chair of the Military Commission, before being awarded the rank of General-Fieldmarshal. Fedyukin examines how von Münnich used his directorship of the Corps, as part of his wider portfolio, to secure and expand its resources, to establish a robust patronage network amongst the officers who staffed the institution, and to ensure that exemplary displays, such as parades, fireworks and commemorative publications, made both its aims and its achievements very visible to the empress Anna and the court. That the reality of regulation and refinement of the cadets was rather more mixed in practice than on the page (or parade ground) is not the point. By the late 1730s, the Corps was firmly established as a desirable model, both as an educational institution and as an example 
of how to realize such a project successfully. Von Münnich's successors at the Corps, from amongst his clients (and his brother), followed the same strategy and its acceptance amongst the post-Petrine elite ensured its continuing development, despite its patron's exile in 1741 .

The final chapter considers the educational projects of empress Elizaveta Petrovna's reign and the shadow of the Cadet Corps' success looms large across the period. Its impact had generally been a negative one for the other service schools, who resented its favored status and funding, while it also served to attract the better candidates from amongst the nobility. However, its successful development also signaled what could be achieved by building an administrative project around educational institutions. A broadly equivalent figure to von Münnich for this chapter is Petr I. Shuvalov who, along with his cousin Ivan, played a leading role in several key educational developments during the 1750s. He was a serial projector from the mid-1740s onwards with a remarkable range of interests, many of which generated a great deal of money and influence for him. Shuvalov's experience was court-based, rather than military, but he targeted the vacant position of Generalfeldzeugmeister in 1753 and used various proposals to aid this bid by outlining the need to improve the training of engineers and artillerymen. This strategy was based on demonstrating his "expertise" which, combined with his connections and his ability to mobilize resources, proved successful. In 1758, he proposed a new institution, the Artillery and Engineering Noble Cadet Corps, which would amalgamate the existing service schools under his authority. As with the Naval Cadet Corps, established after rival projecting by Admiralty Board members in the late 1740 and early 1750 s, the details of the proposal centered on resources and organization - teaching methods and curricula were developed as internal documents subsequently. Shuvalov's plans were only realized after Catherine II's accession, but their intent was clear. His cousin Ivan's patronage of similarly "new" institutions-Moscow University and the Academy of Arts-are also discussed here in projecting terms, along with his ambitious but ultimately unrealized bid to establish an empire-wide system of noble schools, encompassing all existing institutions. In a resonance with the episode that opens the book, the political circumstances changed before it could be pursued, albeit the consequences were not so severe for the former favorite in this case.

Catherine II's active engagement with pedagogical ideas and literature was reflected in her patronage of Ivan Betskoi, the establishment of several commissions on education, and the creation of a national school system during her reign. Yet, as outlined in Fedyukin's conclusion, the trends that had emerged across the preceding decades continued to be at least as influential as the ruler's direct interventions during the first half of her reign. The period saw a very considerable number of educational projects with varying degrees of success, whether under the aegis of existing institutions or as private endeavors, albeit subject to a greater degree of institutionalization and routinization, particularly by the 1780 s. This gradual but irreversible process led to the establishment of the Ministry of Popular Education in 1802, which provided a degree of centralization that can be starkly contrasted with the educational landscape under Peter and his successors. This encapsulates the overall argument of Fedyukin's work - rather than being driven by specific state needs or the ruler's demands, Russian school reform across this period resulted from the enterprising efforts of numerous projectors, both Russian and foreign, who sought to realize their goals by identifying opportunities and bidding for support. The research presented here provides further support for the de- 
centering and demythologizing of the Petrine era, as well as challenging the traditional interpretation of early modern state reform being essentially linked to military or geopolitical necessities. As he rightly argues, it would be virtually impossible to assess accurately the military effectiveness of the graduates of these institutions and, in any case, the educational outcomes are only part of their raison d'être.

Overall, this monograph is the culmination of a wide-ranging and well-rounded research endeavor that illuminates the institutional history of Russian education in its formative stages. It draws on an impressive range of archival resources across five countries and displays a well-grounded engagement with the historiography, both for Russia and for several early modern European states. While there is much to admire here, I found myself with a few minor reservations in the end. The historiographical framework set out in the introduction provides useful context for the critical reevaluation of absolutism and "the well-ordered police state," but might have also included something on the "civilizing process," given the concern with education (p. 8). The discussion of the Ottoman Empire in the conclusion is a reasonable comparison with Russia, certainly, but the previous discussion of other European examples surely challenges the idea that it (and other extra-European states) encouraged particular projecting strategies under the broad label of Westernization (p. 206). The copy-editing might have been a bit more rigorous in places, and it was surprising (albeit, from my background, somewhat nostalgic) to see Henry Farquharson and his colleagues referred to on quite a few occasions in Chapter 1 as "the Brits." However, the publishers are to be commended for including a dozen excellent reproductions of archival documents and engravings throughout the book. Fittingly, then, this book represents a very successful project on the part of its author and one which fully merits its place in the rich vein of international scholarship on early modern Russia of recent decades. 